Revista Brasil. Bot., V.25, n.3, p.251-258, set. 2002

\title{
Primary and secondary development of Cyperus giganteus Vahl rhizome (Cyperaceae)
}

\author{
ANA C. RODRIGUES ${ }^{1}$ and MARIA EMÍLIA M. ESTELITA ${ }^{1,2}$
}

(received: October 11, 2001; accepted: April 10, 2002)

\begin{abstract}
Primary and secondary development of Cyperus giganteus Vahl rhizome (Cyperaceae)). In Cyperus giganteus, like in other Monocotyledoneae, the protoderm, procambium, fundamental meristem and primary thickening meristem (PTM) are differentiated from the rhizome promeristem. The PTM produces the inner cortical parenchyma, endodermis, pericycle and amphivasal vascular bundles, which are formed by the procambium too. After the primary body differentiates, cellular divisions continue only in the pericycle, and originate an irregular vascular system with vessel elements shorter and more branched than those found in the primary growth. This change of activity in the pericycle defines a secondary growth, where the secondary thickening meristem (STM) is the pericycle itself.
\end{abstract}

RESUMO - (Desenvolvimento primário e secundário do rizoma de Cyperus giganteus Vahl (Cyperaceae)). Em Cyperus giganteus, como em outras monocotiledôneas, a partir do promeristema do rizoma diferenciam-se a protoderme, o procâmbio e o meristema fundamental e, ainda, o meristema de espessamento primário (MEP). Este último dá origem ao parênquima cortical interno, endoderme, periciclo e feixes vasculares anfivasais, os quais se formam também a partir do procâmbio. Após a diferenciação do corpo primário, apenas o periciclo permanece em divisão, formando um sistema vascular desalinhado, onde os elementos de vaso são mais curtos e mais ramificados do que aqueles do crescimento primário. Esta mudança de atividade do periciclo caracteriza o crescimento secundário, cujo meristema de espessamento (MES) é o próprio periciclo.

Key words - Cyperus giganteus, Cyperaceae, rhizome development, secondary development

\section{Introduction}

Plant organ differentiation involves the core function of the apical meristems, which form the primary body of the plant. However, in Monocotyledoneae the primary body is also formed by the primary thickening meristem (PTM).

According to Rudall (1991), the PTM is found in a pericyclic region and is responsible for the primary thickening of the stem, adventitious root formation, and connections in the vascularization of the stem, roots and leaves. The author emphasizes that functions of the PTM are extremely meaningful in the interpretation of growth habits, since they define the shape of the shoot apex and, consequently, of the plant as a whole. Analyses of Allium cepa L. by DeMason (1979) have shown similarities between the PTM and the cambium zone, made up of tangentially flattened cell layers; according to protein and RNA analyses, the PTM is continuous with the apical meristem.

Some Monocotyledoneae also have secondary growth (STM), such as those of Super Order Liliiflorae,

\footnotetext{
1. Universidade de São Paulo, Instituto de Biociências, Departamento de Botânica, Caixa Postal 11461, 05422-970 São Paulo, SP, Brazil.

2. Corresponding author: estelita@ib.usp.br
}

which includes the families Agavaceae, Dioscoreaceae, Xanthorrhoeaceae, Asphodilaceae, Dasyponaceae and Iridaceae (Tomlinson \& Zimmerman 1969, Dahlgren $\&$ Gifford 1982), and the family Eriocaulaceae, a taxon of the Super Order Commeliflorae (Rudall 1991).

Several situations were identified in species with STM showing its relationship with the PTM. According to Stevenson (1980a) some studies point out a continuous or discontinuous feature between PTM and STM, depending on the species analyzed.

Concerning Cyperaceae, Guillard (1878) analyzed the PTM in Scirpus, and Rudall (1991) mentioned its presence in species of Fimbristylis from Brazil. In Cyperus esculentus L., commonly referred to as sedge, Gifford \& Bayer (1995) mention the presence of a circular, lateral meristem that forms roots, vascular and conjunctive tissues, and which is located below a bulb apex; it is not considered a STM, though.

The objective of the present study is to analyze the organogenesis of Cyperus giganteus Vahl rhizome, focusing basically on the radial growth of the organ, a topic rarely discussed in Cyperaceae family.

\section{Material and methods}

Samples of the rhizome of Cyperus giganteus Vahl were fixed in FAA 70 (Johansen 1940) for approximately 72 hours 
and stored in $70 \%$ ethanol, followed by ethylic dehydration and paraffin inclusion. Serial longitudinal and cross-sections were taken from the shoot apex and stained with $1 \%$ safranin in $96 \%$ ethanol and $0,5 \%$ astra blue in $2 \%$ tartaric acid (Roesler 1962).

The presence of lignin and suberin were confirmed with phloroglucinol and Sudan IV, respectively (Johansen 1940). Polarized light was used to make the Casparian strip more evident.

For scanning electron microscopy observations, the material was previously macerated in hydrogen peroxide and acetic acid (Franklin 1945) for 72 hours, approximately. It was dehydrated in an ethylic series, dried under natural conditions, covered with gold and analyzed in an electronic microscope Zeiss DSM 940.

\section{Results}

The shoot apex is congested and the apical meristem is surrounded by several leaf primordia (figure 1) forming a sharp tip. In apical meristem, the procambium strands are distributed throughout the stem (figure 1).

The primary thickening meristem, or PTM, appears in subsequent differentiation levels and is made up of periclinally divided cell layers laterally positioned near the leaf primordia base (figures 1-2). Further down, the PTM is located outside the procambium strands (figure 2), and plays in both directions (figures 2-4). The centrifugal activity of this meristem results in radial parenchyma rows developed by periclinal and anticlinal divisions of the initial meristematic cells and their derivatives (figures 2-4). Centripetally, the PTM produces amphivasal vascular bundles and parenchyma (figures 3,4 ), thus playing a major role in the primary thickening of the organ. The vessel elements of those bundles are elongated and differentiated by intrusive growth, originating branchings in the final walls (figures 12-14).

The PTM activity is gradually reduced, as shown by the strong differentiation of the surrounding cells. The endodermis is evident in the cortex layers (figure 5). Later, the endodermis and several contiguous layers are lignified (figure 6). At this time, phenolic compounds are deposited in the endodermis, differentiating it from the other lignified layers (figures 7, 8). In this phase, the pericycle (figures 7,8 ) is a residue of the PTM and changes its activity producing - centripetally only phloem and xylem without a specific vascular bundle pattern (figures 7,8 ). Therefore, in this phase the pericyle can be the secondary thickening meristem, or STM, itself. The vessel elements produced by the STM are shorter and have more branched than those produced by the PTM; branchings are found both in the final and lateral walls (figures 15-17).

The PTM produces adventitious roots, which can be observed early, close to the apical meristem; the STM produces adventitious root too (figures 18, 19). Finally, the pericycle becomes lignified.

The endodermis in the rhizome was identified in differentiation (figures 5,7), and by the presence of suberin and phenolic compounds in different phases of deposition (figures 7,8 ).

The endodermis can be followed upon the development of adventitious roots (figures 18, 19). The continuity of the endodermis between the rhizome and the root is only observed when it is considerably thickened (figures 18, 19).

Although at first the cortical parenchyma is homogeneous, idioblasts containing phenolic compounds are soon identified (figures 2,5 ). In the following phases of differentiation, the distinction between external and inner cortex takes place (figure 9) and the latter is made up of braciform cells that form conspicuous intercellular spaces (figure 6). The intense activity of the PTM and its derivatives suggests that the inner cortex is fully developed from such meristem (figure 9). The external cortex contains some cell layers that result from periclinal and anticlinal divisions and that are lignified (figures 10, 11). The cortex region has collateral and amphivasal bundles involved in leaf and bud vascularization; these bundles are surrounded by a lignified sheath and its inner layer represents the endodermis (figure 8).

The central region of the rhizome shows vascular bundles originated from the procambium (showing proto and metaxylem) and from the PTM (showing only metaxylem). They are scattered in a parenchyma with idioblasts, similar to those previously mentioned.

\section{Discussion}

Despite anatomical information of Metcalfe (1971) on Cyperus giganteus, the stem development analysis of Cyperus species is restricted to studies of Gifford \& Bayer (1995) on C. esculentus. Rudall (1991) agrees with several authors stating that the PTM is formed not only by a single layer like the vascular cambium, but by several ones, as clearly shown in $C$. giganteus.

Amphivasal bundles, adventitious roots, most of the cortex, endodermis and pericycle are differentiated from the PTM of $C$. giganteus, and the last two structures are more easily identified after the endodermis thickening. 

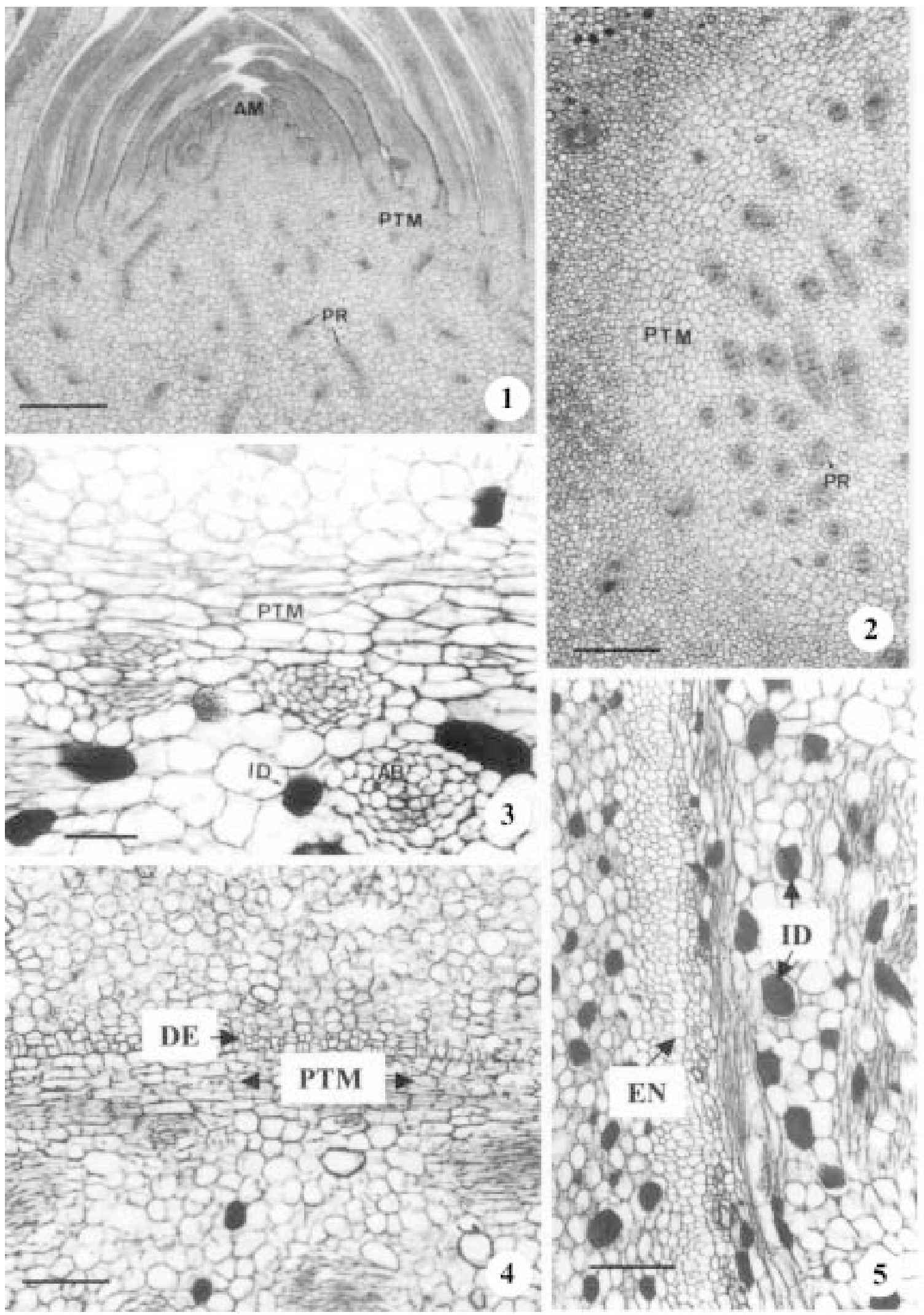

Figures 1-5. 1. Longitudinal section of the shoot apex. Apical meristem with tunica-corpus organization. Bar $=180 \mu \mathrm{m} .2-5$. Cross-sections showing the PTM. Figure 2. Bar $=180 \mu \mathrm{m}$; Figure 3. Bar $=40 \mu \mathrm{m}$; Figures 4 and 5. Bar $=90 \mu \mathrm{m}$. (AM- apical meristem; $\mathrm{PTM}=$ primary thickening meristem; $\mathrm{PR}=$ procambium; $\mathrm{PTM}=$ primary thickening meristem; $\mathrm{PR}=$ procambium; $\mathrm{AB}=$ amphivasal bundle; $\mathrm{EN}=$ endodermis; $\mathrm{DE}=$ derivatives; $\mathrm{ID}=$ idioblast $)$. 

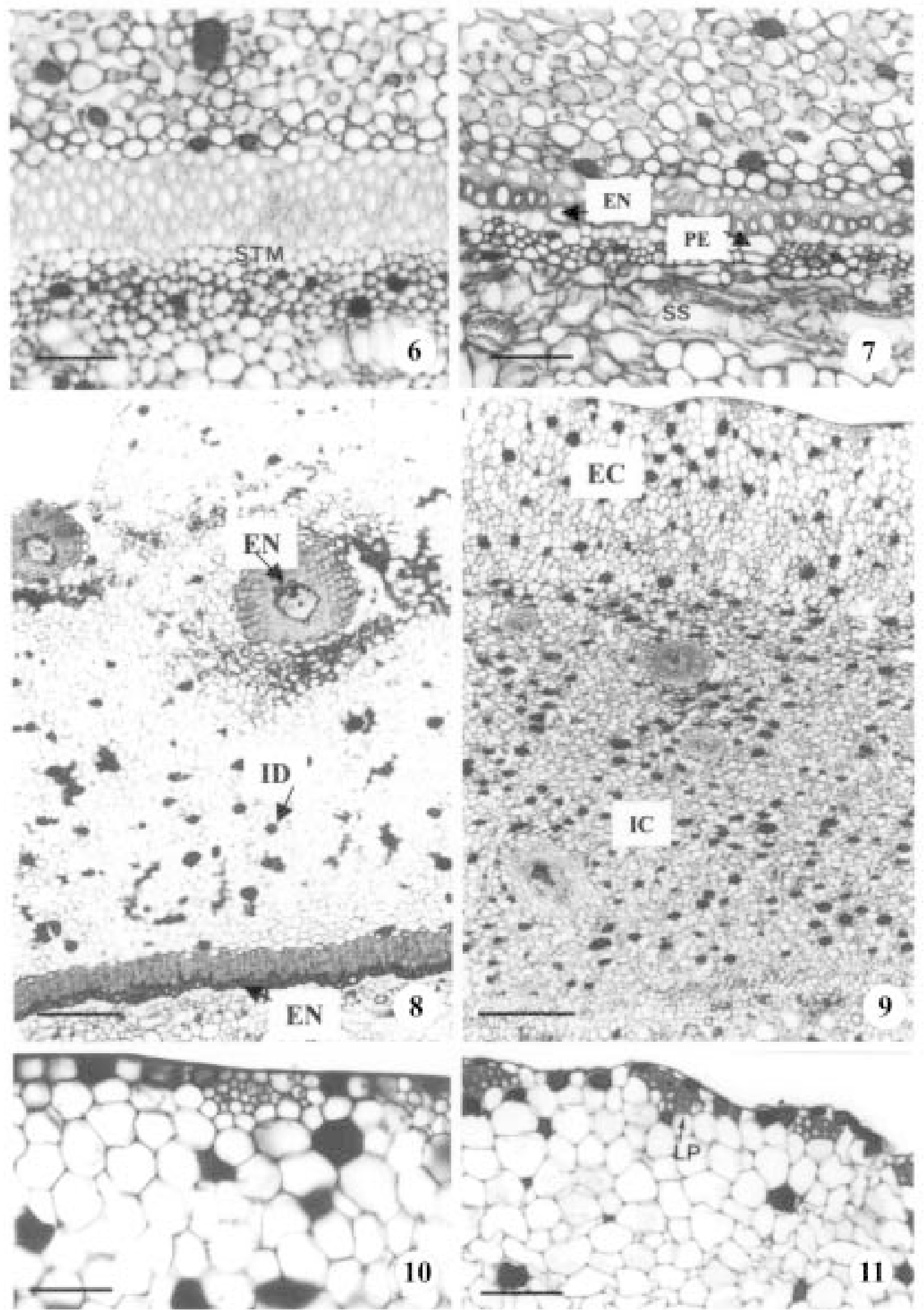

Figures 6-11. 6-8. Cross-sections emphasizing the STM. Figures 6 and 7. Bar $=90 \mu \mathrm{m}$; Figure 8. Bar $=180 \mu \mathrm{m}$. 9-11. Cross-sections. 9. Inner and external cortex. Bar $=180 \mu \mathrm{m}$. 10. Hypodermis with parenchyma cells being lignified. Bar $=90 \mu \mathrm{m}$. 11. Hypodermis with lignified parenchyma cells. $\mathrm{Bar}=90 \mu \mathrm{m}$. (STM $=$ secondary thickening meristem; $\mathrm{EN}=$ endodermis with phenolic compounds; $\mathrm{PE}=$ pericycle; $\mathrm{SS}=$ secondary vascular system; ID = idioblast; $\mathrm{EC}=$ external cortex; IC = inner cortex; LP = lignified parenchyma). 

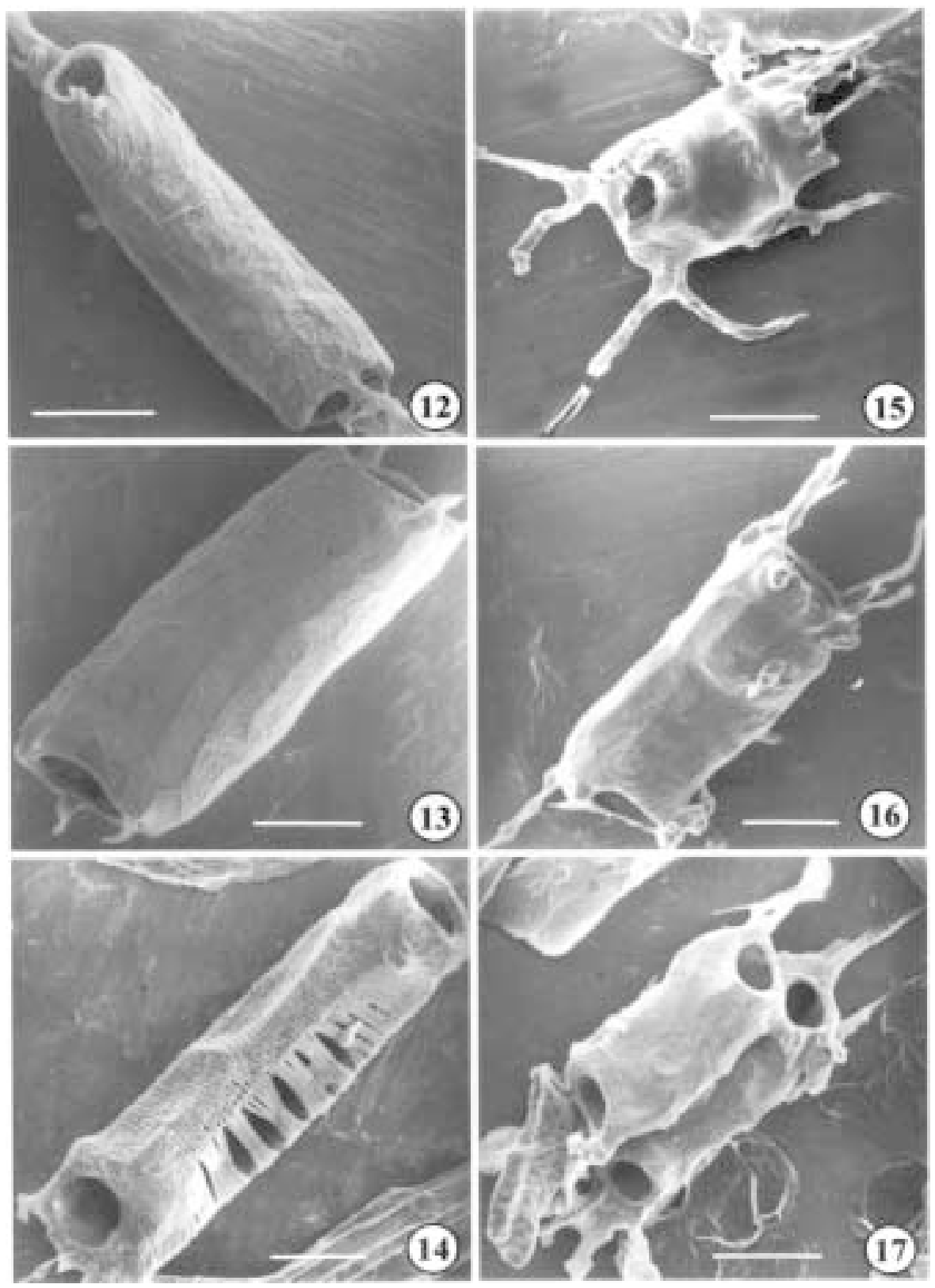

Figures 12-17. Scanning electron microscopy showing vessel elements. 12-14. Elements from the PTM. Bar $=40 \mu \mathrm{m}$. 15-17. Elements from the STM. Bar $=60 \mu \mathrm{m}$.

According to the traditional literature (Esau 1965), the cortex is differentiated from the fundamental meristem. Cyperus obtusatus (J. Presl.) Mattf. \& Kük., as well as all species with a fully active PTM, go against such statement, since the cortex of those plants has a mixed origin. The external cortex, formed by several sub-epidermal layer divisions originated from the fundamental meristem, is here referred to as hypodermis and confirms the continuity from the roots up to the leaves (Metcalfe 1971), like in other Cyperaceae (Williams 1947). Anderson (1974) reports the occurrence of a hypodermis in roots of Spartina species and in root and stem of Distichlis spicata (L.) Greene and Juncus roemerianus Scheele. Zimmermam \& Tomlinson (1969) and Estelita (1993) also report a hypodermis in Dracaena fragrans Ker-Gawl. and Remirea maritima Aubl. stems.

Idioblasts with phenolic compounds are frequent in Cyperaceae (Metcalfe 1971, Estelita \& Caldeira 1997), and is also found in other groups, like Iridaceae (Rudall 1984).

In the apex region, the PTM is always made up of several cell layers, as mentioned by Tomlinson \& Zimmerman (1969), and Stevenson (1980a). In 


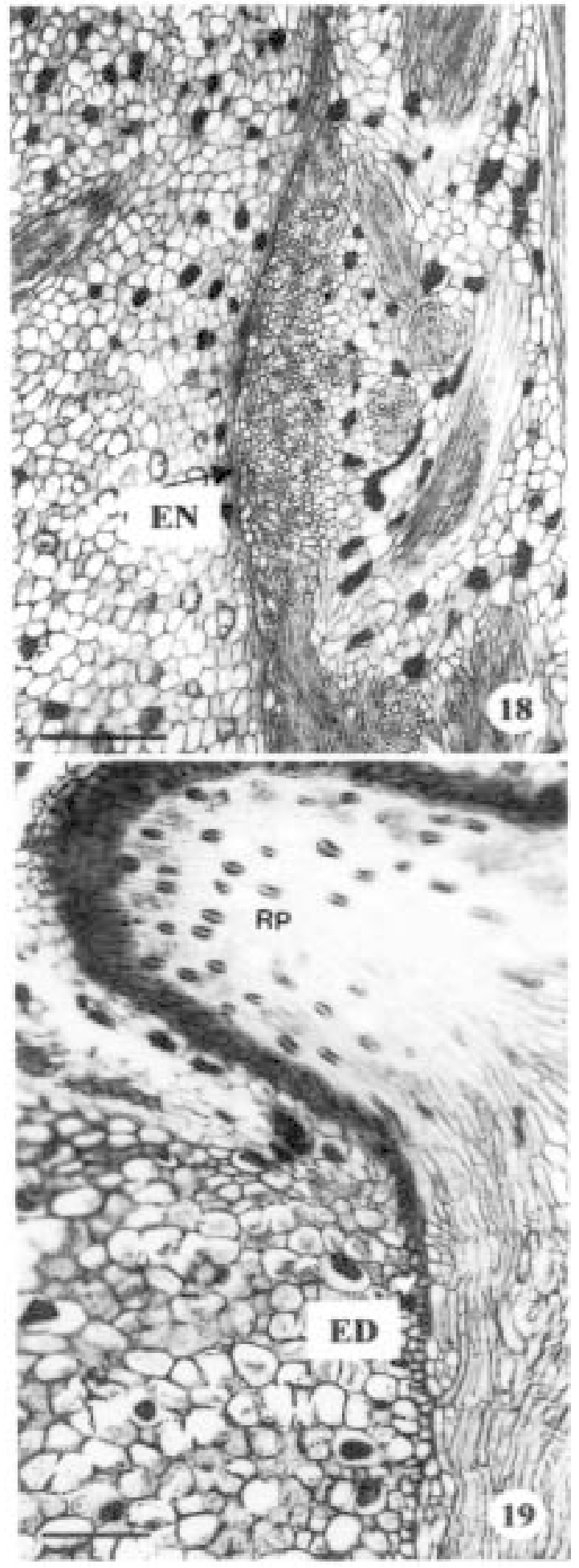

Figures 18-19. Cross-sections showing the development of adventitious root. Figure 18. Bar $=90 \mu \mathrm{m}$. Figure 19 . $\mathrm{Bar}=45 \mu \mathrm{m} .(\mathrm{RP}=$ root primordium; $\mathrm{EN}=$ endodermis $)$.

Cyperus giganteus the number of PTM layers is reduced in the basipetal direction, where the derivatives stop being produced as reported by DeMason (1983) for
Allium cepa (Liliaceae).

The PTM activity seems to vary according to growth habits. In Cyperus giganteus, whose rhizome is around $8 \mathrm{~cm}$ of diameter, the PTM is active in both directions, and in C. esculentus rhizome with only a few millimeters, the PTM produces only radial parenchyma rows, with no inward activity (Gifford \& Bayer 1995).

Many authors have made reference to the endodermis in the rhizome, like Evans (1965), who reports to Eleocharis acuta R.Br. not only one endodermis, but two. Other authors refer to an endodermoid layer (Wills \& Briscol 1970, Metcalfe 1971, Wills et al. 1980, Rudall 1984). Gifford \& Bayer (1995) only state that the inner of the cells of the cortex of C. esculentus rhizome become lignified. However, they emphasize that Rosenheck (1992) recorded the presence of Casparian strips in the tuber of these species. In C. giganteus, the endodermis is discernable by the impregnation of suberin and phenolic compounds (Van Fleet 1961) and by the strips in the young root.

Apparently, the presence of branched tracheary elements produced by the PTM has never been recorded in the literature; Yulong \& Liese (1997) mentioned branched elements in the nodal region of Gramineae. They are identified as protoxylem, though.

Bendixen (1973) mentions the pericyclic origin of adventitious roots in the genus Cyperus. However, Wills et al. (1980) stated an endodermal origin. Gifford \& Bayer (1995), unlike the mentioned authors, showed that the root primordium derives from the PTM. According to the present study, both Gifford \& Bayer (1995) and Bendixen (1973) are right, since the pericycle is a part of the PTM.

The literature defines secondary growth as a result of the cell division activity that takes place after primary tissue maturation in the region in question. Authors like DeMason (1983) emphasize such definition on referring to its rare presence in Monocotyledoneae. In Cyperus giganteus, the STM activity is different from that found in the PTM and occurs after the differentiation of primary tissues, thus defining the presence of secondary growth. The STM is the pericycle itself, and can be identified by its adjacent position to endodermis. Moreover, the vascular system produced by this meristem is not organized in well-defined vascular bundles. Rudall (1984) mentioned the "pericyclic lateral meristem" on referring to the PTM localization.

Another feature that confirms the statements above 
is the production of shorter vessel elements, with several branches resulting from intrusive growth.

According to Rudall (1984), in the rhizome of Iridaceae species, the STM is found in a pericyclic region, with inward activity only. In Cyperus giganteus, the STM is the pericycle itself, is formed by a single cell layer, and also has a centripetal activity. Rudall (1984) also acknowledges an outward activity, like the one stated by Cheadle (1937) in Furcraea (Agavaceae).

Cheadle (1937) mentions the presence of branched tracheary elements in the secondary xylem of several Monocotyledoneae. Similarly, Esau (1965) describes elements with intrusive growth originated from that type of growth, and Diggle \& DeMason (1983a) observed intrusive growth in tracheary elements of the stem of Yucca whipplei Torr. Intrusive growth may result from stem contraction, which explains a larger number of branchings in the vessel elements produced by STM, since in width growth, especially in contracted stems, does not occur internode elongation.

Cheadle (1948), on referring to the secondary growth in Monocotyledoneae, stated that none of the species analyzed until then, including Dracaena and Cordyline (Agavaceae), have vessel elements. In Cyperus giganteus, their presence in the secondary tissues reveals a more specialized status among Monocotyledoneae.

Metcalfe (1971), on describing the rhizome of several Cyperaceae species, noticed that in a specific stele region it is often impossible to recognize individual vascular bundles due to the several fusions and winding course of the vascular elements, which suggests the presence of secondary growth of the extra-fascicular type. Gifford \& Bayer (1995) also suggest the presence of secondary growth in Cyperus esculentus, but stated the absence of several characteristics, such as centripetal longitudinal vascular bundles formation. However, Cheadle (1937) emphasized the presence of several secondary growth variations in Monocotyledoneae. The present study considers the secondary growth according to the previous definition and it was verified not only in C. giganteus, but also in several species of Cyperus, in Eleocharis, Rhynchospora, Killinga and Fimbristylis.

Stevenson (1980a) observed root formation from the STM in Beaucarnea recurvata Lem. (Agavaceae), as verified in the present study.

The continuity of the STM with the PTM as observed in Cyperus giganteus, was also reported for Cordyline terminalis Kunth (DeMason \& Wilson 1985) and for Dracaena fragrans (Zimmermann \& Tomlinson 1969) both Agavaceae. Stevenson (1980a) showed that in Beaucarnea recurvata (Agavaceae) the PTM and the STM are continuous in seedling stages, but discontinuous in adult stages. Diggle \& DeMason (1983 a, b) concluded that in Yucca whipplei (Agavaceae) both meristems are different phases of the same one. In C. giganteus, the continuous feature between PTM and STM is assisted by the absence of intercalary meristem resulting in a congested rhizome with very short internodes.

The analysis of Cyperus giganteus emphasizes the Rudall (1984) statement that PTM and STM are different phases of the same meristem and that both cause growth in girth.

Phylogenetic studies mention the plesiomorphous condition of secondary growth that often occurs in larger species, that is, in arbustive and arborial species that require vascular and supporting systems according to their size. Waterhouse (1987) suggests that pachycaulis like Dracaena, are Monocotyledoneae ancestors, and that several of them share the same gonduanic origin. Hong \& Soh (1993) verified the secondary growth in a pteridophyte (Botrychium ternatum (Thunb.) Sw. Ophioglossaceae) and Stevenson (1980b) in eighteen species of Cycadales (Gymnospermae).

Rudall (1984) assumes that, in Iridaceae, the STM either evolves from a persistent STM or was retained as a primitive character. In Cyperus esculentus the STM is considered a more primitive condition and occurs in large herbaceous species with pachyrhizome, such as the species in $C$. giganteus and $C$. papyrus $\mathrm{L}$.

Acknowledgments - The authors thank FAPESP (process 97/05516-0) and CNPq (process 30710/84) for supporting and Dr. Alberto Ribeiro for the use of the Electron Microscopy Laboratory.

\section{References}

ANDERSON, C.E. 1974. A review of structure in several North Carolina salt marsh plants. In Ecology of halophytes (R.J. Reimold, \& W.H. Queen, eds.). Academic Press, New York.

BENDIXEN, L.E. 1973. Anatomy and sprounting of yellow nutsedge tubers. Weed Science 21:501-503.

CHEADLE, V.I. 1937. Secundary growth by means of a thickening ring in certain monocotyledons. Botanical Gazette 98:535-555.

CHEADLE, V.I. 1948. Types of vascular bundles in the Monocotyledoneae and their relation to the late metaxylem conducting elements. American Journal of Botany 35:486-496. 
DHALGREEN, R.M.T. \& CLIFFORD, H.T. 1982. The monocotyledons: a comparative study. Academic Press, London.

DeMASON, D.A. 1979. Histochemistry of the primary thickening meristem in the vegetative stem of Allium cepa L. American Journal of Botany 66:347-350.

DeMASON, D.A. 1983. The primary thickening meristem: definition and function in monocotyledons. American Journal of Botany 70:955-962.

DeMASON, D.A. \& WILSON, M.A. 1985. The continuity of primary and secondary growth in Cordyline terminalis (Agavaceae). Canadian Journal of Botany 63:1907-1913.

DIGGLE, P.K. \& DeMASON, D.A. 1983a. The relationship between the primary thickening meristem and the secondary thickening meristem in Yucca whipplei Torr. I. Histology of the mature vegetative stem. American Journal of Botany 70:1195-1204.

DIGGLE, P.K. \& DeMASON, D.A. 1983b. The relationship between the primary thickening meristem and the secondary thickening meristem in Yucca whipplei Torr. II Ontogenetic relationship within the vegetative stem. American Journal of Botany 70:1205-1216.

ESAU, K. 1965. Plant anatomy. John Wiley \& Sons, New York.

ESTELITA, M.E.M. 1993. Anatomia dos órgãos vegetativos de Remirea maritima Aubl. (Cyperaceae). Naturalia 18:123-134.

ESTELITA, M.E.M. \& CALDEIRA. W. 1997. Ultrastructure of phenolic storage cells in leaf and scape of Cyperus obtusatus (Cyperaceae), a Kranz species. Acta Microscopica 6. Supl. 8:642-643.

EVANS, P.S. 1965. Intercalary growth in the aerial shoot of Eleocharis acuta $\mathrm{R}$. Br. Prodr. I Structure of the growing zone. Annals of Botany 29:205-217.

FRANKLIN, G.L. 1945. Preparation of thin sections of synthetic resin and wood-resin composites, and a new marcerating method for wood. Nature 155:51.

GIFFORD, E.M. \& BAYER, D.E. 1995. Development anatomy of Cyperus esculentus (yellow nutsedge). International Journal of Plant Sciences 156:622-629.

GUILLARD, M.D.A. 1878. L'anatome comparée et le développement des tissus de la tige dans les monocotylédones. Annales des Sciences Naturelles Botanique sér. 6. 5:1-176.

HONG, S.S. \& SOH, W.Y. 1993. Vascular meristem and secondary growth, in the rhizome of Botrychium ternatum. Phytomorphology 34:251-260.
JOHANSEN, D.A. 1940. Plant microtechnique. McGrawHill Book Co., New York.

METCALFE, C.R. 1971. Anatomy of the monocotyledons. Cyperaceae. Oxford University Press, Oxford, v. 5.

ROESLER, K.R. 1962. Die Nadel der Schwarzkiefer-Massen produkt and Kunstwert der Natur. Mykrokosmos 61:33-36.

ROSENHECK, L.A. 1992. Cyperus esculentus tuber production, viability, and anatomy as affected by glyphosate. MSc. Thesis, University of California, Davis.

RUDALL, P. 1984. Taxonomic and evolutionary implications of rhizome structure and secondary thickening in Iridaceae. Botanical Gazette 145:524-534.

RUDALL, P. 1991. Lateral meristems and stem thickening growth in monocotiledons. The Botanical Review 57:150-163.

STEVENSON, D.W. 1980a. Radial growth in Beaucarnea recurvata. American Journal of Botany 67:476-489.

STEVENSON, D.W. 1980b. Radial growth in the Cycadales. American Journal of Botany 67:465-475.

TOMLINSON, P.E. \& ZIMMERMANN, M.H. 1969. Vascular anatomy of monocotyledons with secondary growth - An introduction. Journal of the Arnold Arboretum 50:159-179.

VAN-FLEET, D.S. 1961. Histochemistry and function of the endodermis. The Botanical Review 27:165-220.

WATERHOUSE, J.T. 1987. The phylogenetic significance of Dracaena - type growth. Proceedings of the Linnean Society of New South Wales 109:129-138.

WILLIAMS, B.C. 1947. The structure of the meristematic root tip and origin of the primary tissues in the roots of vascular plants. American Journal of Botany 34:455-462.

WILLS, G.D. \& BRISCOE, G.A. 1970. Anatomy of Purple nutsedge. Weed Science 18:631-635.

WILLS, G.D., HOAGLAND, R.E. \& PAUL, R.N. 1980. Anatomy of Yellow nutsedge (Cyperus esculentus). Weed Science 28:432-437.

YULONG, D. \& LIESE, W. 1997. Anatomical investigations on the nodes of bamboos In The bamboos (G.P. Chapmam, ed.). Academic Press, New York, p. 269-283.

ZIMMERMANN, M.H \& TOMLINSON, P.E 1969. The vascular system in the axis of Dracaena fragrans (Agavaceae). 1. Distribution and development of primary strands. Journal of the Arnold Arboretum 50:370-383. 